\title{
Code Switching in an EFL Environment
}

\author{
Natassa Stylianou-Panayi \\ Department of English Language and Linguistics, Frederick University, Cyprus
}

Copyright (C) 2015 by authors, all rights reserved. Authors agree that this article remains permanently open access under the terms of the Creative Commons Attribution License 4.0 International License

\begin{abstract}
When referring to Bilingualism, code switching seems to be an important issue as it is connected to: (a) the use of L1 while teaching the L2; (b) the native teacher, or the non-native teacher, in an EFL classroom environment; (c) along with the importance of the Critical Period Hypothesis concerning language acquisition. The use of L1 in the classroom largely depends on the teacher, and whether he / she is native or non-native. On the other hand, these days many classrooms tend to be multicultural and multilingual as well, so there might be confusion in some EFL classroom environments on the L1, and on how many languages code switching occurs. Acquiring a second language is largely connected to the Critical Period Hypothesis (CPH), and whether children are able to learn a language to the extent, they can learn their mother tongue, before the age of puberty. When referring to two languages and the ease of switching from one into another, the reference to the $\mathrm{CPH}$ becomes even more important. The present paper provides reference on recent research and the literature review on code switching and identifies the factors facilitating or inhibiting it. The paper focuses on whether code switching in an EFL classroom environment occurs because of the difficulties learners have when communicating from one language to the other; whether having a native teacher helps students or not and how code switching is influenced by several factors, such as the speakers' age.
\end{abstract}

Keywords Code Switching, Critical Period Hypothesis, Native and Non-native Teacher

\section{Introduction}

Within an EFL classroom, the target language is expected to be the main language in the classroom, both as the language of instruction and communication. Nonetheless, the use of L1 and the switch from one to the other is often seen in foreign language classrooms. Teachers consider this situation as negative, but at the same time inevitable.

What seems to influence this switch from L1 to L2 and vice versa, is the teacher and whether he/she is native or non-native, the age of the learners and the fact that many classrooms are multicultural and multilingual nowadays.

Code switching can also exist within a bilingual house, or community, not necessarily in a language classroom. Milroy and Muysken [25](pp.7) defined it by saying that 'code switching is the alternative use by bilinguals of two or more languages within the same conversation'.

Different definitions of the term 'code switching' were suggested during the past years by a variety of linguists. Gal 1988, as cited in Wardhaugh, [35] (pp.101) stated that 'code switching is a conversational strategy used to establish, cross or destroy group boundaries; to create, evoke or change interpersonal relations with their rights and obligations'.

Cook [6](pp.83) defined it by saying that 'code switching is the process of going from one language to the other in mid-speech when both speakers know the same languages'. Lightbown [16](pp.598) suggested that 'it is the systematic alternating use of two languages or language varieties, within a single conversation or utterance'.

Wardhaugh [35](pp.101) explained it by saying that 'people are usually required to select a particular code whenever they choose to speak, and they may also decide to switch from one code to another, or to mix codes, even within sometimes very short utterances and thereby create a new code'.

Discussion has also been raised in terms of the types of code switching, not just on definitions and meanings. Gumperz [10] for example, suggested two different categories of code switching; situational and conversational. As Gardner-Chloros [9] (pp.361) explained, 'situational code switching could be regarded as changes in the language choice whereas conversational code switching is motivated by factors within the conversation itself'.

Poplack [28] based on her research, suggested three types of code switching; tag switching, inter-sentential switching and intra-sentential switching. Tag switching occurs when a tag phrase is inserted from one language into the other, inter-sentential can be seen when learners switch a clause or sentence from one language to the other and intra-sentential, is when speakers switch from one language to the other within the same sentence.

The reason why code switching exists is also important, 
despite the different definitions and types. As Holmes [11] (pp.35) suggested, 'a speaker may similarly switch to another language as a signal of group membership and shared ethnicity with an addressee'.

\section{Purpose of the Study}

Despite the fact that a lot of related studies already exist, the purpose of the current study is to focus on the reasons for code switching within an English foreign language classroom rather than a general term, which, as mentioned previously, it can also occur on an everyday basis by bilinguals, or multilinguals, in their homes and communities. In addition, the current study does not provide any new evidence but instead makes a reference on previous research studies as far as whether the mother tongue should exist during second language teaching; the role of the teacher and learners' age.

\section{Code switching in the EFL Classroom}

As it can be seen from the research [8], code switching is unavoidable in an EFL classroom environment. Factors such as the teacher and the use of mother tongue within the language classroom seem to be one of the most important reasons for code-switching.

The target language will only be used when the teacher is native or does not share the same L1 with all the students. Some studies $[4,13,21]$ have shown that using the mother tongue in the classroom, and therefore code switching from L1 to L2, is not necessarily an unfortunate situation as long as it is controlled by the teacher without going over the top with it. Since the teacher is the one who can allow code switching, researchers $[17,34]$ have suggested that this should be considered as an advantage within the foreign language classroom.

The discussion that follows provides clear evidence on the reasons code switching takes place in foreign language classrooms, the importance of the mother tongue and whether there is a preference of having a native teacher on a non-native one.

\subsection{Using the L1 While Teaching the L2}

There has been an important reference, during the past years, whether teachers and students should or should not use the $\mathrm{L} 1$ while teaching the L2. Some researchers are in favour of using L1 while teaching the L2 $[6,31]$ but there are also others $[3,23]$ who disagreed and believed that learners do not have to understand everything said by the teacher and thus there is no real need for code switching. They also believed that one is able to avoid the use of the mother tongue by following certain techniques within the second language classroom whereas Chambers [3] explained that language becomes real and learners built their own language system only when the L2 is being used within classroom.

Avoiding the use of $\mathrm{L} 1$ in the foreign language classroom has been suggested since the $19^{\text {th }} \mathrm{C}$ with the existence of the Direct Method and later on with the Audio-lingual Method [29]. In classroom environments, such as the foreign language ones, it is the only place for most students where they can communicate by using the L2; and as Krashen [12] argued, students' exposure to the target language leads to real communication and effective learning.

On the other hand, researchers such as Cook [6] and Sterns [31] stated that, students' mother tongue is important in foreign language classrooms. Cook [7] argued that the classroom 'is a natural code switching situation' (p. 406) and that code switching is 'a highly skilled activity' (p. 408).

Cook [7] and Scrivener [30] not only disagreed, but also explained the importance of the L1, by giving suggestions and some techniques on how to use the mother tongue while teaching the L2. Along with his suggestions, Cook [7] also explained the importance of encouraging the use of the target language rather than eliminating the mother tongue, and that this should be the teachers' focus.

Cook [7] (pp.418) also explained that code switching is not necessarily a situation, which should be avoided as in fact he moved on by saying that deliberate and systematic use of the L1 will 'develop L2 activities, such as code-switching, for later real life use'.

Littlewood and $\mathrm{Yu}$ [17] agreed and suggested ways on how to use the L1 and the target language in the classroom, especially when, in most foreign language classrooms, the teacher has the same mother tongue with the learner. They also referred to a variety of studies $[20,32]$ and their similar results; teachers choose to use the L1 for grammar explanation and discipline.

Turnbull [33] also agreed with the use of L1 during the classroom, but he also stated that teachers should not overuse it and do not forget that, for some learners, the only contact they have with the L2 is during classroom activities.

Levine [15] (pp.334) explained that there is indeed a place for the mother tongue in the language classroom in terms of 'anxiety reduction or simple validation of learners' identity in their dominant language'.

Different studies throughout the past years have also shown that the amount of L1 usage within the EFL classroom can vary, depending on the situation, the learners and the teacher.

Duff and Polio [8] examined thirteen different L2 classes and found that the L1 was used on continuously and that some teachers did not realize they were code switching.

Gearon as cited in Turnbull [33] also examined six secondary French teachers' and found that most code switching occurred within the sentence, and that all teachers were aware of the use of the mother tongue, because they felt that using the $\mathrm{L} 1$ helped students understand more.

Turnbull [33] studied four teachers of French in Canadian secondary schools and found that the use of L1 (English) varied from $28 \%$ to $76 \%$. 
Macaro [21] explained that, since code switching occurs because learners find it easier to communicate in classrooms where the teacher has the same L1 as the learners, it is extremely difficult to use only the target language. He also suggested that if there was no use of the L1, and teachers had to explain new vocabulary, it would be much more difficult for learners to learn, and that teachers would probably find other ways, such as miming. He explained that if the same mime is repeated long enough, the students may stop listening to the spoken language altogether and just understand from the mime' (pp.73-74).

Research has shown $[20,22]$ that both teachers and students code switch from the L1 to the L2, and, Cook [7] suggested that new teaching methods and techniques should be used and adopted by teachers, in order for L1 to be positively used within the foreign language classroom.

\subsection{Native and Non-native Teachers}

The issue of having a native, or a non-native teacher, has worried a lot of researchers $[5,18,19,21]$ and whether one is more accepted than the other, largely depends on the learners and their demands and beliefs.

Traditionally, having native teachers in a school was seen as more privileged rather than a non-native teacher. Sutherland [32], talked about the advertisements of private language schools that often make a reference to native teachers, and consider it as an important qualification.

Honey as cited in Sutherland [32] talked about the necessity of having native teachers in an EFL environment since they would be able to guide non-native teachers. A native teacher would therefore use the target language throughout the lesson and not have to switch from L1 to L2, and vice versa. This, however, does not necessarily mean that it would offer better results. As Zimmerman [36] explained, native teachers might use a certain variety of the language and, therefore, cause more confusion to the learners. On the other hand, non-native teachers have a clearer accent and are more aware of the learners' feelings and thoughts.

What seems to be quite important is the fact that there are more non-native teachers rather than native teachers. Sutherland [32] talked about the advantages and disadvantages of having both kinds of teachers. $\mathrm{He}$ explained that non-native teachers have the advantage of using their L1 as well to explain certain difficulties; that is, when the teacher and the learner have the same mother tongue. Sutherland [32] quoted Seidlhofer and explained that non-native teachers might choose to use L1 for further explanation, but native teachers have the advantage of providing learners with new language when needed.

When teachers code switch from one language to the other, they help learners experience the ease of using the target language without overusing the $\mathrm{L} 1$ and forgetting about the L2. As Macaro [21] explained, according to some findings, teachers choose to code switch and use the L1, when learners have difficulties and become irritated. Teachers, according to
Macaro [21], either bilinguals or natives, seem to be convinced that code switching might be regrettable but at the same time necessary during the lesson.

Ferguson examined how, native teachers, and non-native teachers, were seen by their students in terms of students' general attitudes, and findings showed that there was a preference towards non-native teachers. Meadows and Muramatsu [24] also examined students' attitudes towards native teachers or non-native teachers in an American University. They chose four different languages, Japanese, Chinese, Spanish, Italian, and organized them in two groups; Asian and European. Data showed mixed results; Italian and Asian students showed preference towards the native teachers, whereas Spanish students preferred non-native teachers.

Shin and Kellogg 2007, as cited in Sutherland [32] found that a Korean teacher of English asked her students more questions compared to a native teacher. Sutherland [32] concluded, based on the results from Shin and Kellogg that 'the claim that native teachers provide the most exposure to English may not always be true'.

Therefore, a non-native teacher may not be a disadvantage since it does not depend only to them but to students as well. Research $[24,32]$ has shown that learners will switch from L1 to L2 despite the teachers' mother tongue.

\subsection{Learners' Age and Second Language Acquisition}

Ever since Penfield and Roberts [27] and later Lenneberg [14] have argued about the timeframe on learners' age of second language acquisition and learning, there has been a lot of discussion on whether such a period actually exists and, if so, how it influences learners.

It has been argued by Lenneberg [14] that learners who acquire a second language are able to do so until the age of puberty; a time also known as Critical Period Hypothesis $(\mathrm{CPH})$.

Some have supported this view, but at the same time it was declined by others; and according to a variety of studies $[1,2$, 26 it is possible to learn a second language after the age of puberty.

As far as code switching in an EFL classroom, younger learners seem to be the ones who code switch more, only because learners at that age do not have the knowledge or vocabulary needed to fully understand and communicate by only using the target language. Macaro [21] suggested that if there was no use of the mother tongue, while teaching the target language, other issues would be raised. He provided as an example the listening activities and the pre-listening ones. If the language the students are going to hear in the listening activity contains considerable amounts of new language, it may be extremely difficult for the teacher to provide the contextual clues in the L2 as these will be as new as the language the students are going to be listening to in the actual aural text' (p. 76).

Whereas, when teaching older students, code switching 
should only be used for guidance and making learners feel more confident about the tasks they need to fulfill.

When a bilingual child learns two L1s, it is different from learning the $\mathrm{L} 1$ and then the $\mathrm{L} 2$ in a later stage. A bilingual child has been exposed to two or even more languages from birth, whereas the second language learner, usually, from the age of five and onwards comes across the new language. Despite the fact that, some might argue that the exposure in both situations, occurs within the Critical Period, it is still not the same, because, most of the times, L2 learning takes place in monolingual environments, and thus learners only use it within the classroom.

Most of the research, focused on whether $\mathrm{CPH}$ exists, and, therefore, there is little evidence on code switching and the role of the learners' age.

\section{Conclusions}

As it has been earlier discussed, the issue of code switching in an EFL classroom seems not only to be unavoidable but necessary. The importance on this is when and how code switching should take place. As some of the researchers explained [7,21,32], teachers ought to find a place for the mother tongue, while teaching English, in order to help learners achieve the best possible results, without forgetting the target language.

Other than finding the perfect place for the $\mathrm{L} 1$ in a foreign language classroom, teachers should also remember the importance of the L2 and in what ways it can help learners to actively participate in the classroom rather than just follow their teachers' guidelines.

When teachers choose to code switch from the L2 to the L1, and vice versa, they should only choose to do so for better results, to motivate students or even to clarify certain tasks. It is quite understandable that code switching will occur more with young learners rather than older learners, because of young learners' limited knowledge of vocabulary.

As it has been shown from previous research, opinions and beliefs on learners' preferences as far as their teacher varies, so as the amount of code switching that takes place in the classroom. Each classroom is unique and each teacher, native or not, should decide on the techniques which will be used for better understanding, based upon their learners' needs.

\section{REFERENCES}

[1] Birdsong, D. (1992). Ultimate attainment in second language acquisition. Language, 68, 706-755.

[2] Bongaerts, T., Van Summere, C., Planken, B., \& Schils, E. (1997). Age and ultimate attainment in the pronunciation of a foreign language. Studies in Second Language Acquisition, 19, 447-465.
[3] Chambers, F. (1991). Promoting use of the target language in the classroom. Language Learning Journal, 4, 27-31.

[4] Cohen, A.D. \& Brooks-Carson, A. (2001). Research on direct versus translated writing: Students' strategies and their results. Modern Language Journal, 85 (2), 169-188.

[5] Cook, V. (1999). Going beyond the native speaker in language teaching. TESOL Quarterly, 33, (2), 185-209

[6] Cook, V. (2000). Second language learning and teaching. Beijing: Foreign Language Teaching and Research Press

[7] Cook, V. (2001). Using the first language in the classroom. The Canadian Modern Language Review, 57, (3), 402-423

[8] Duff, P.A., \& Polio, C.G. (1990). How much foreign language is there in the foreign language classroom? Modern Language Journal, 74, 154-166

[9] Gardner-Chloros, P. (1997). Code-switching: Language selection in three Strasbourg department stores. In Coupland, N., \& Jaworski, A. (Eds) Sociolinguistics: A reader and coursebook. Hampshire, UK: Palgrave, 361-375

[10] Gumperz, J. J. (1982). Discourse Strategies. Cambridge: Cambridge University Press

[11] Holmes, J. (2001). An introduction to sociolinguistics. Essex: Longman

[12] Krashen, D. (1985). The Input Hypothesis. Issues and implications. Essex: Longman, 1-32

[13] Lally, C.G. (2000). First language influences in second language composition: The effect of pre-writing. Foreign Language Annals, 33 (4), 428-432.

[14] Lenneberg, E. (1967). Biological foundations of language. New York: Wiley

[15] Levine, G. S. (2014). Principles for code choice in the foreign language classroom: A focus on grammaring. Language Teaching, 47, 332-348

[16] Lightbown, P. M. (2001). L2 instruction: time to teach. TESOL Quarterly, 35, (4), 598-599

[17] Littlewood, W. \& Yu, B. (2011). First language and target language in the foreign language classroom. Language Teaching, 44, (1), 64-77

[18] Llurda, E. (2004). Non-native speaker teachers and English as an International Language. International Journal of Applied Linguistics, 14, (3), 314-323

[19] Lung, J. (1999). A local teacher views the native English teacher scheme in Hong Kong. TESOL Matters, 9, (3)

[20] Macaro, E. (2001b). Analysing student teachers' codeswitching in foreign language classrooms: Theories and decision making. Modern Language Journal, 85 (4), 53 1-548

[21] Macaro, E. (2006). Codeswitching in the L2 classroom: A communication and learning strategy. In Llurda, E. (Ed.), Non-native Language Teachers. Perceptions, Challenges and Contributions to the Profession, Oxford: Oxford University Press, 63-84

[22] Macaro, E. \& Mutton, T. (2002). Developing language teachers through a co-researcher model. Language Learning Journal, 25, 27-39. 
[23] Macdonald, C. (1993). Using the target language. Cheltenham, UK: Mary Glosgow Publications

[24] Meadows, B., \& Muramatsu, Y. (2007). Native speaker or non-native speaker teacher? A report of students preferences in four different foreign language classrooms. Arizona Working Papers in SLA and Teaching, 14, 95-109

[25] Milroy, L., \& Muysken, P. (1995). One speaker, two languages: Cross-disciplinary perspectives on code switching. Cambridge, UK: Cambridge University Press

[26] Moyer, A. (1999). Ultimate attainment in L2 phonology: The critical factors of age, motivation and instruction. Studies in Second Language Acquisition, 21, 81-108.

[27] Penfield, W., \& Roberts, L. (1959). Speech and brain-mechanisms. Princeton. New Jersey: Princeton University Press.

[28] Poplack, S. (1980). Sometimes I'll start a sentence in Spanish y Termino en Espanol: towards a typology of code-switching. Linguistics, 18, 581-616

[29] Richards, R., \& Rodgers, T. (2004). Approaches and methods in language teaching. Cambridge: Cambridge University
Press.

[30] Scrivener, J. (2005). Learning Teaching. Oxford: Macmillan Books for Teachers.

[31] Stern, H.H. (1992). Issues and options in language teaching. Oxford: Oxford University Press.

[32] Sutherland, S. (2012). Native and non-native English teachers in the classroom: A re-examination. Arab World English Journal, 3, (4), 58-71

[33] Turnbull, M. (2001b). There is a role for the L1 in second and foreign language teaching, but Canadian Modern Language Review, 57, 531-540

[34] Turnbull, M., \& Arnett, K. (2002). Teachers' uses of the target and first languages in second and foreign language classrooms. Annual Review of Applied Linguistics, 22, 204-218

[35] Wardhaugh, R. (2006). An introduction to Sociolinguistics. Oxford, UK: Blackwell Publishing

[36] Zimmerman, L. (2007). Standard English in the EFL classroom. ELT Journal, 61(2), 164 - 166. 